\title{
ORTHOTOPIC SMALL
} INTESTINE TRANSPLANTATION IN DOGS WITH SYSTEMIC GRAFT DRAINAGE

\author{
Flávio Henrique Ferreira GALVÃO ${ }^{1}$, Eduardo POMPEU², \\ Nicolas PANAJOTOPOULOS ${ }^{1}$, Vinicius Rocha SANTOS ${ }^{1}$, \\ Telésforo BACCHELLA ${ }^{1}$ and Marcel Cerqueira César MACHADO ${ }^{1}$
}

ABSTRACT - Background - Small intestine transplantation has been accepted worldwide to treat complex cases of intestinal failure. Canine intestinal transplantation model is important in training the surgical technique and to study the complications of this procedure. Systemic graft venous drainage is frequently performed in clinic, although the consequences of this partial meso-caval shunt have not been studied in detail. Aim - To describe the surgical technique and clinical outcome of a canine intestinal transplantation model using mesenteric-caval graft drainage. Method - Adult mongrel dogs from University of São Paulo Animal Facility, São Paulo, SP, Brazil, were used as donors and recipients in ten consecutives orthotopic intestinal transplantation with mesenteric-caval venous drainage. Clinical examination and body weight measurement were performed daily in all animals. Necropsy was performed in animals presenting moribund state (lethargic posture, diarrhea and loss of over $35 \%$ of body weight) to determine cause of death and histological changes. Results - Three recipients died before day 2 from technical complications and were excluded from the experiment. The remaining seven animals developed signs of graft rejection with onset on days 3-4 and died or were sacrificed presenting severe graft rejection between days 7-9. Necropsy and histology of the graft confirmed the diagnosis of severe acute cellular rejection. Conclusion - Small intestine transplantation with systemic drainage in dogs courses with analogous and lethal outcome between postoperative day 7 to 9 due to strong graft rejection. This model serves as an excellent pre-clinical model to study the main complications related to this transplantation.

HEADINGS - Intestine, small, transplantation. Rejection. Dog.

\section{INTRODUCTION}

Intestinal failure is defined as the inability of the native gastrointestinal tract to maintain nutritional, fluid and electrolyte support without total parenteral nutrition $(\mathrm{TPN})^{(1,2,5)}$. There are about 40,000 patients dependent on TPN in North America ${ }^{(8)}$. It has been estimated that 2-3 persons per million of world population per year will develop intestinal failure and $15 \%-20 \%$ of these patients could be candidates for intestinal transplantation ${ }^{(4,8)}$.

Home TPN is very expensive, promotes poor quality of life and is associated with a high morbidity and mortality of $5 \%-25 \%$ patients per year ${ }^{(1,2,4,5,8)}$.

Advances in biotechnology have improved outcome in small intestine transplantation (SIT) at certain centers. Successful intestinal transplantation allows patients with intestinal failure to return to a more normal lifestyle ${ }^{(1,2,4,5,8,17)}$. Over 900 SIT have already been performed worldwide for patients with the following TPN complications: 1. loss of venous access; 2 . development of liver failure; 3 . frequent central line-related sepsis; and 4. frequent severe dehydration ${ }^{(1,2,5,17)}$.

In Brazil, small bowel transplantation was first performed by Professor Masayuki Okumura at the University of Sao Paulo. Professor Okumura was one of the world pioneers of clinical small bowel transplantation, performing the second and the third case of this procedure described in the medical literature ${ }^{(14,13)}$. His distinction in this topic inspires researches and transplant surgeons worldwide.

Unfortunately the intestine remains the most challenging abdominal organ to transplant $t^{(1,2,5,13,14,17)}$. Despite considerable progress in clinical management, the outcome after SIT is still unsatisfactory compared to other organ transplants such as heart, liver and kidney ${ }^{(1,2,5,13,14,17)}$. The main problems related to intestinal transplantation include poor graft function, strong rejection, complications in immunosuppressive therapy, infections and complex surgical technique ${ }^{(9,13,14,17)}$.

${ }^{1}$ Discipline of Liver Transplantation and Surgery and ${ }^{2}$ Animal Facility Center, University of São Paulo, Medical School, São Paulo, SP, Brazil.

Address for correspondence: Dr. Flavio H. F. Galvão - Av. Dr. Arnaldo, 455 - Disciplina de Transplante e Cirurgia do Fígado - 3o andar - sala 11 - $01246-903$ - São Paulo, SP, Brazil. E-mail: fgalvao@usp.br 
Research in animals is important for the development of new approaches to control the complications of intestinal transplantation. Canines have been widely used as a more clinically relevant large animal model. Experiments with dogs have provided information to directly improve the clinical results of intestinal grafts ${ }^{(11,12,15,20)}$. Furthermore, it is important for transplant surgeons to learn the surgical technique and complications of SIT in large animals before clinical application ${ }^{(15)}$.

Canine model of intestinal transplantation promotes a strong rejection due the high amount of lymphoid tissue present in the intestinal graft and is a unique tool to study immunology after this transplantation ${ }^{(11,12,15,20)}$.

Isolated intestinal graft is indicated for intestinal failure without significant underlying liver or other organ failure and accounts for about $50 \%$ of the SIT indications ${ }^{(1,5,13,14,17)}$. It may be performed with portal or systemic venous drainage of the graft, which may be through the liver or into the inferior vena cava, respectively ${ }^{(3,11,18,19)}$. Portal drainage is theoretically more physiologic; however systemic venous drainage is more demanding in a clinical setting due to frequent surgical difficulties while performing mesenteric-portal anastomosis in the recipient ${ }^{(3)}$.

The consequences of systemic venous drainage concerning immunologic and metabolic alterations have not been studied in detail on canine models of intestinal transplantation ${ }^{(15)}$.

This study was undertaken to describe the surgical technique and the outcome of 10 orthotopic SIT in mongrel dogs with systemic graft drainage.

\section{METHOD}

Animals - Ten male and 10 female adult mongrel dogs weighing 16 to $24 \mathrm{~kg}$ were used as donors and recipients, respectively. They were obtained from Animal Facility of the University of São Paulo Medical School - FMUSP, São Paulo, SP, Brazil, and kept in conventional facilities for 4 weeks before the experiment, under daily clinical observation. During this period they were treated for intestinal parasites and submitted to periodic laboratories analysis to ensure good animal condition for the experiment. All procedures in this study were performed according to the guidelines of the Council on Animal Care at the FMUSP.

Experimental design-Donors and recipients were fasted 12 hours for solid food and 8 hours for liquids, before the SIT procedure. Enrofloxacina IM $(5 \mathrm{mg} / \mathrm{kg})$ was administrated four hours before the operation and the same dose was repeated on postoperative days (POD) 1,2 and 3. Orthotopic SIT was performed using mesentericcaval drainage. After operation the animals were fasted for solid food during POD 1 and observed daily. Body weight was measured each morning. Tissue from the graft and small intestine from the recipient obtained at postmortem examination were fixed with $10 \%$ buffered formalin and stained with hematoxylin and eosin (H-E). Tissues from thymus, cervical lymph nodes, mesenteric lymph nodes, liver and spleen were stored at $-80^{\circ} \mathrm{C}$ for further studies.

Surgical technique - The adopted surgical technique was described by LILLEHEI et al. ${ }^{(1)}$ with the systemic graft drainage modification.

Donor operation - Anesthesia was induced with intravenous sodium thiopental $(25 \mathrm{mg} / \mathrm{kg})$ and maintained with methoxyisoflurane (1.0\%) and oxygen using positive pressure mechanical ventilation. Systemic blood pressure and ECG were continuously monitored during the anesthesia. The abdomen was opened through a midline incision. The thin connective tissue between the duodenum and the colon was divided to the jejunum ligament. The mesocolon was carefully separated from the pancreas and epiploon. The colon and terminal ileum were separated from the remaining small bowel after the middle colic vases and ileocolic vases were tied with 4-0 silk sutures. The dissected superior mesenteric vein was separated from the pancreas up to the splenic vein after carefully liberation of its tributaries. The posterior peritoneum was opened and the abdominal aorta was dissected $2 \mathrm{~cm}$ above and below the emergence of the superior mesenteric artery. The connective tissue between the superior mesenteric artery and vein containing the inferior pancreatic duodenal artery and first duodenal artery was tied and dissected. In this step the animal received $300 \mathrm{U} / \mathrm{kg}$ of intravenous heparin. The abdominal aorta was incised and a Carrel's patch with the mesenteric artery was obtained. The superior mesenteric vein was incised at the splenic vein confluence. The jejunum was divided about $5 \mathrm{~cm}$ distal to the jejunum ligament and the jejunum mesentery divided down to superior mesenteric vessels. The ileum was divided about $5 \mathrm{~cm}$ from the ileocecal valve and its mesentery divided down to the superior mesenteric vessels. The entire small intestine with its vascular pedicle was removed from the peritoneal cavity and perfused on the back table with cold $\left(4^{\circ} \mathrm{C}\right)$ lactated Ringer's solution. The animals were sacrificed with a lethal injection of $10 \% \mathrm{KCl}$.

Recipient operation - After thiopental induction and methoxyflurane anesthesia similar to that described above for the donor, the abdomen was opened through a midline incision. The infra-renal segment of abdominal aorta and vena cava were dissected and a segment of about $3 \mathrm{~cm}$ from both vessels were isolated between vascular clamps. End-to-side mesenteric-aorta and mesentericcaval anastomosis with continuous 7-0 polypropylene suture were performed (Figure 1). After revascularization of the graft the small intestine from the recipient were excised, leaving approximately 10 $\mathrm{cm}$ of both proximal jejunum and terminal ileum. The intestinal continuity was restored with a continuous end-to-end anastomosis at the jejunum and ileum using 5-0 polypropylene. The abdominal incision was closed with a continuous suture.

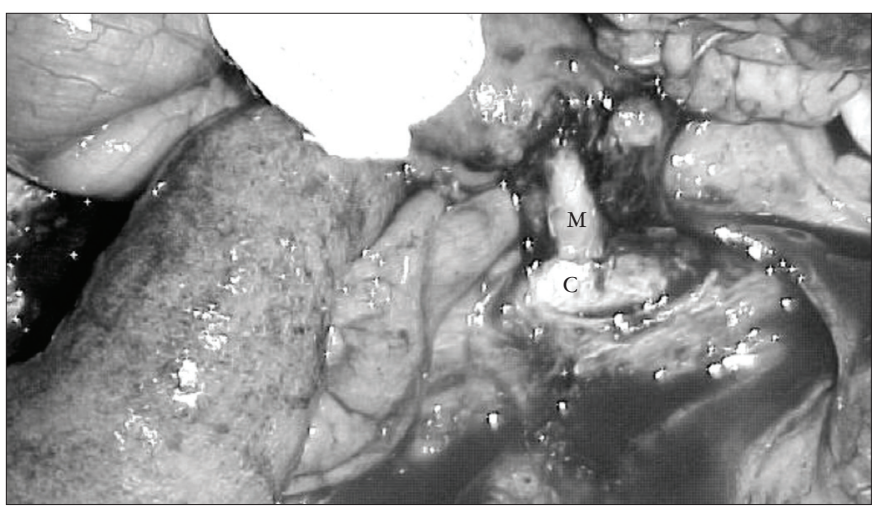

FIGURE 1 - Necropsy of the recipient at post-operative day 8 showing peritonitis and patent end-to-side mesenteric-caval anastomosis. M - Donor mesenteric vein. C - Recipient vena cava 
Experimental end point - When animals died or were sacrificed by injection of anesthetic, they were presenting clinical signs of severe acute graft rejection. The signs included: diarrhea, abdominal distention, lethargic posture or loss of more than $35 \%$ of preoperative body weight.

Histological assessment of acute rejection - The histological diagnosis and degree of acute rejection were analyzed with a similar method of grading criteria described elsewhere ${ }^{(20)}$. This method is based on the particular histomorphology that describes three subclassifications of acute rejection: mild, moderate and severe.

\section{RESULTS}

Outcome - Two animals died during surgery from anesthesia complications and one at POD 2 due to bleeding. These three animals were considered technical failure and excluded from the experiment. In seven recipients, the transplantation was considered successful, the graft color recovered immediately after reperfusion and survival reached more than 6 days. After intestinal transplantation, these animals resumed good activity the next morning and started eating within 1-2 days. They developed diarrhea starting from POD 3 that progressed with hemorrhage at POD 5, abdominal distention, lethargic posture and progressive loss of body weight. The animals died ( $\mathrm{n}$ $=3$ ), or were sacrificed in moribund state due to graft rejection ( $\mathrm{n}$ $=4$ ) between POD 7-9. The main signs of severe rejection and the percentage of its incidence were: diarrhea $(100 \%)$, loss of more than $35 \%$ of preoperative body weight $(100 \%)$, lethargic posture $(86 \%)$ abdominal distention ( $42 \%)$.

Autopsy findings - At the time of the autopsy, all recipients presented moderate inter-intestinal adhesions at peritoneal cavity and severe inflammation in the graft, mainly in the Peyer's patch. An important enlargement of the mesentery due to edema and inflammation was also observed. Peritonitis was observed in four recipients (Figure 1). The small intestine from the recipient presented a normal aspect.

Histopathology - The histological features in the graft revealed severe acute rejection in all recipients that reached the experimental end point with extensive villous damage, necrotic changes of the superficial mucosa, severe mixed inflammatory cell infiltration and considerable amount of lymphocytic cryptitis and vasculitis (Figure 2). Transmural necrosis, mainly in Peyer's patch was also observed in five recipients. The recipients' small intestine was considered normal.

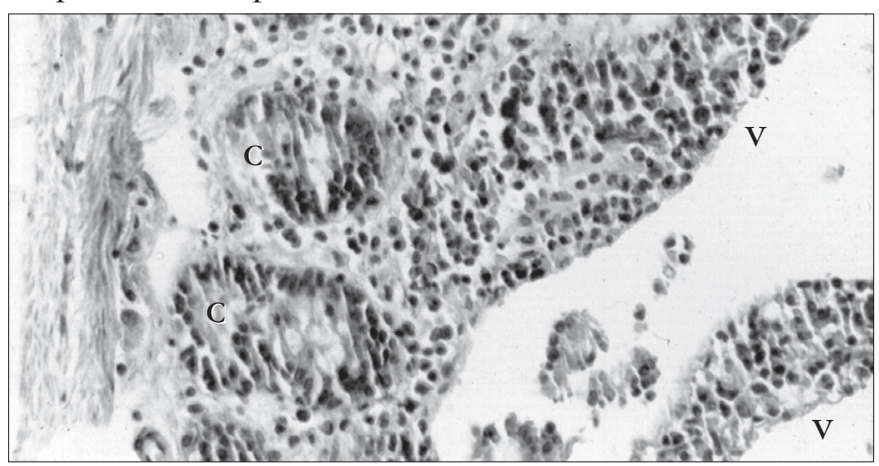

FIGURE 2 - Severe acute graft rejection with extensive villous (V) damage due inflammatory cell infiltration and cryptitis (C) (HE, 400X)

\section{DISCUSSION}

Clinical SIT has been increasing, however this procedure is still considered to be experimental, under rigid protocols ${ }^{(1,2,5)}$. Thus, research in dogs is a relevant issue for the development of new methods to treat efficiently the complications related to $\operatorname{SIT}^{(11,12,15,21)}$

According to the anatomic position of the intestinal graft, there are basically two surgical models for intestinal transplantation: heterotopic and orthotopic. Heterotopic SIT is performed exteriorizing both ends of the graft as stomas, permitting serial analysis of the graft ${ }^{(6,23)}$. However the intestinal stream isolation causes mucosal atrophy, increased intestinal permeability, overgrowth of potentially pathogenic bacteria, translocation and others artifacts that hinder physiologic studies of the graft $\mathrm{t}^{(7,16)}$.

The orthotopic model of SIT was used in the present experiment and is performed positioning the graft in continuity with remnant digestive tract from the recipient. Recipient's outcome and survival are more correlated with the complications of the graft ${ }^{(6,9,23)}$ and this model permits analysis of graft physiology. In an orthotopic model variation, the ileum anastomosis is performed by end-to-side method and the distal extremity of the graft is exteriorized as a stoma ${ }^{(1,7)}$. This approach permits analysis of the graft through the stoma by enteroscopy ${ }^{(1,7)}$. In the present study we did not perform stomas because we were interested in animal and graft evaluation under natural conditions.

There is still a controversy about the consequences and complications caused by systemic graft venous drainage. Experiments comparing portal and systemic graft drainage showed virtually similar survival rates, liver function test results, serum ammonia levels, amino-acid distribution, liver histology, protein synthesis, and bacterial translocation ${ }^{(11,19,20)}$. On the other hand, other experiments observed on systemic venous drainage altered ammonia and amino-acid levels that resemble those found in models of hepatic encephalopathy ${ }^{(10)}$. Furthermore, in a recent clinical trail, a higher incidence of bacteremia and pneumonia was observed in the systemically drained group, suggesting a higher rate of bacterial translocation in these patients ${ }^{(3)}$.

From the immunological standpoint, there is experimental evidence that previous portal vein administration of donor cells is related with tolerance to grafts from the same donor ${ }^{(18)}$. Portal drainage promotes an inflow of passenger lymphocytes from the graft through the liver. This situation may promote clearance of donor antigens by the liver and could favor a lower rate of rejection $^{(24)}$. Thus cell trafficking of mesenteric lymphocytes through systemic venous drainage could be related to a poor impact on the immunological evolution of the graft $\mathrm{t}^{(9)}$. We are currently designing an experiment to investigate this hypothesis.

In a pre-clinical model of SIT with portal graft drainage performed at University of Pittsburgh, mongrel dogs were used to investigate the best dosage and the immunosuppressive effect of tacrolimus. They observed in the positive control group (dogs submitted to SIT without immunosuppressant) similar results in terms of clinical outcome, technical failure and survival rate as those observed in the present study ${ }^{(23)}$. The findings from University of Pittsburgh suggest that portal drainage itself was unable to improve graft and recipient survival in dogs submitted to SIT without immunosuppressant regiment. 
Graft rejection was extremely strong in the present study, leading the recipients to a dramatic and lethal outcome within a few days. Male to female combination was used to avoid the interference of different sex combinations on immunological reaction after transplantation and for further investigation on microchimerism using Y chromosome as a marker ${ }^{(12)}$. The clinical and histologic evolution of rejection in the present study was similar to that observed when SIT was performed between fully allogenic combination of inbred rats (inbred ACI rats as donors, and inbred Lewis rats as recipients) without immunosuppression ${ }^{(21)}$.

Rejection is one of the most important limitations to the routine indication of $\operatorname{SIT}^{(1,2,5)}$. The homogeneous profile of the rejection observed in this research may allow studies to evaluate the metabolic consequences of systemic drainage, to test immunosuppressive drug metabolism and new methods for tolerance induction.

We conclude that the dog model of orthotopic SIT with systemic drainage cause a strong graft rejection with a fatal course between POD 7 to 9. This model serves as an excellent pre-clinical model to study the main complications related to this transplantation.

\section{ACKNOWLEDGMENTS}

We are grateful to Dr. Silvia Ortiz, Cláudia Pestana Ribeiro, Vicente de Paula Silveira and Ismael de Paula Barros from Animal Facility Center - FMUSP for their assistance in animal care.

Galvão FHF, Pompeu E, Panajotopoulos N, Santos VR, Bacchella T, Machado MCC. Transplante ortotópico de intestino delgado em cães com drenagem sistêmica do enxerto. Arq Gastroenterol 2005;42(3):182-5.

RESUMO-Racional-O transplante de intestino delgado é atualmente indicado para tratar casos complexos de falência entérica. Transplante intestinal em cão é importante modelo experimental para treino da técnica cirúrgica e para estudar as complicações desse procedimento. Drenagem sistêmica do enxerto é freqüentemente realizada nos transplantes clínicos, embora sua conseqüência seja desconhecida. Objetivo - Descrever a técnica cirúrgica e a evolução clínica e histopatológica de modelo de transplante de intestino em cão. Método - Cães mestiços adultos foram usados como doadores e receptores em 10 transplantes ortotópico de intestino delgado com drenagem mesentérico-cava do enxerto. Exame clínico e verificação do peso corpóreo dos receptores foram realizados diariamente. Sacrifício sob anestesia e necropsia foi realizado quando os animais apresentavam estado clínico precário (postura letárgica, diarréia, e perda de peso maior do que 35\%) ou óbito, para determinação do diagnóstico. Resultados - Três recipientes morreram antes do segundo dia de pós-operatório por erro técnico e foram excluídos do experimento. Os setes receptores restantes apresentaram início de sinais clínicos de rejeição entre os dias 3-4 de pós-operatório e morreram ou foram sacrificados apresentando rejeição severa do enxerto entre os dias 7-9. Necropsia e histologia do enxerto confirmaram o diagnóstico de rejeição aguda grave. Conclusão - O transplante de intestino delgado com drenagem sistêmica em cão cursa com similar e letal evolução entre os dias de pós-operatórios 7-9 devido a forte rejeição do enxerto. Este modelo é excelente para o estudo pré-clínico das complicações do transplante de intestinal.

DESCRITORES - Intestino delgado, transplante. Rejeição. Cão.

\section{REFERENCES}

1. Abu-Elmagd K, Reyes J, Bond G, Mazariegos G, Wu T, Murase N, Sindhi R, Martin D, Colangelo J, Zak M, Janson D, Ezzelarab M, Dvorchik I, Parizhskaya M, Deutsch M, Demetris A, Fung J, Starzl TE. Clinical intestinaltransplantation: a decade of experience at a single center. Ann Surg 2001;234:404-16.

2. American Gastroenterological Association Medical Position Statement Short Bowel Syndrome and Intestinal Transplantation. Gastroenterology 2003;124:1105-10.

3. Berney T, Kato T, Nishida S, Mittal N, Tector AJ, Levi D, Madariaga J, Nery JR, Ruiz P, Tzakis AG. Systemic versus portal venous drainage of small bowel grafts: similar long-term outcome in spite of increased bacterial translocation. Transplant Proc 2002;34:961-2.

4. DiMartini A, Rovera GM, Graham TO, Furukawa H, Todo S, Funovits M, Lu S, Abu-Elmagd K. Quality of life after small intestinal transplantation and among home parenteral nutrition patients. JPEN J Parenter Enteral Nutr 1998;22:357-62.

5. Galvão FH, Waitzberg DL, Bacchella T, Gama-Rodrigues J, Machado MC. Small Intestine Transplantation. Arq Gastroenterol 2003;40:118-25

6. Goffi FS, Fujimura I, de Tolosa EM, Behmer OA, Kieffer J, Carnevale J, Lemos PP, Costa LF, Ayres SS, Freitas Neto AG, Bastos EE. Experimental study on small intestine heterotopic homologous transplantation: preliminary data. Rev Paul Med Mar 1971;773:57-62.

7. Grant D, Zhong R, Hurlbut D, Garcia B, Chen HF, Lamont D, Wang PZ, Stiller C, Duff J. A comparison of heterotopic and orthotopic intestinal transplantation in rats. Transplantation 1991;515:948-54

8. Howard L, Hassan N. Home parenteral nutrition. 25 years later. Gastroenterol Clin North Am 1998;272:481-512.

9. Koh I, Cohen Z, Levy G, Plapler H, Wojcik D, Gorczynski RM. Migration patterns of lymphocytes following syngeneic heterotopic small bowel transplantation in rodents. Immunol Lett 1993;381:3-9.

10. Koltun WA, Madara JL, Smith RJ, Kirkman RL. Metabolic aspects of small (1987)

11. Lillehei RC, Goot B, Miller FA. The physiological response of the small bowel of dog to ischaemia including prolonged in vitro preservation with successful replacement and survival. Ann Surg, 150:54-60.

12. Okuda T, Ichikawa N, Zhu Y, Chun HJ, Demestris AJ, Nalesnik MA, Rudert B, Trucco M, Starzl TE, Murase N. Quantitative analysis of microchimerism with Y-chromosomespecific PCR in canine small bowel transplantation. Transplant Proc 2000;32:1278.
13. Okumura M, Fujimura I, Ferrari AA, Nakiri K, Lemos PC, de Andréa EA, Bahdur R, Marek SR, Yasbek Neto MJ, Posso JM, da Fonseca AM, Iriya K, Antonascio F, de Faria JF, de Barros Magaldi J, de Paula W, Raia AA. Transplantation of the small intestine. Case report. Rev Hosp Clin Fac Med São Paulo 1969;24:39-54.

14. Okumura $\mathrm{M}$, Mester $\mathrm{M}$. The coming of age of small bowel transplantation: a historical perspective. Transplant Proc 1992;24:1241-2.

15. Pirenne J. Contribution of large animal models to the development of clinical intestinal transplantation. Acta Gastroenterol Belg 1999;62:221-5.

16. Price BA, Cumberland NS, Clark CL, Pockley AG, Wood RF. Evidence that orthotopic transposition following rat heterotopic small bowel transplantation corrects overgrowth of potentially pathogenic bacteria. Transplantation 1996;61:649-51.

17. Report of International Intestinal Transplantation Registry disponivel $<\mathrm{http}$ ://www. intestinaltransplantation.org $>$. Accessed December 01, 2004.

18. Schraut WH, Abraham VS, Lee KK. Portal versus caval venous drainage of small bowel allografts: technical and metabolic consequences. Surgery 1986;99:193-8.

19. ShafferD, DifloT, Love W, Clowes GH, MakiT, MonacoAP. Immunologic and metabolic effects of caval versus portal venous drainage in small-bowel transplantation. Surgery 1988;104:518-24.

20. Starzl TE, Kaupp HA. Mass homotransplantation of abdominal organs in dogs. Surgical Forum 1960;11:219-29.

21. Tanabe M, Murase M, Demetris AJ, Hoffman RA, Nakamura k, Fugisaki S, Galvão FH, Todo S, Fung J, Starzl TE. The influence of donor and recipient strain in isolated small bowel transplantation in rats. Transplant Proc 1994;26:3733-40.

22. Tolosa EM, Goffi FS, Behmer OA, Fujimura I, Lemos PC, Freitas Neto AG, Nakashima Y. Homologous transplantation of the small intestine in dogs. Histological evaluation of rejection. Rev Assoc Méd Bras 1971;17:303-6.

23. Yoshimi F, Nakamura K, Zhu Y, Suzuki M, Funakoshi Y, Carrieri G, Wu Y, Furukawa H, Demetris AJ, Todo S. Canine total orthotopic small bowel transplantation under FK 506. Transplantation Proceedings 1991;23:3240-2.

24. Yu S, Nakafusa Y, Flye MW. Portal vein administration of donor cells promotes peripheral allospecific hyporesponsiveness and graft tolerance. Surgery.1994;116:229-34.

Recebido em 6/11/2004 Aprovado em 31/3/2005. 